\title{
Research on the Reform of Teaching Mode In the Application of "Internet +" Background
}

\author{
Liyun Wang \\ College of Computer and Information Engineering, Zhengzhou University \\ of Industrial Technology, Zhengzhou Henan 451150,China
}

912725921@qq.com

\section{Keywords: Internet +; College Education; Teaching Reform; Practical Teaching}

\begin{abstract}
Internet $+"$ is through the information and communication technology and the use of the Internet platform, the Internet and traditional industries, including all walks of life are combined in the new field to create a new Ecology. Local application - oriented colleges and universities should aim at improving the quality of personnel training under the "Internet + ", highlighting the important position of practical teaching in the teaching of applied colleges and universities. "Internet + Education" for the development of applied colleges to add new vitality and vitality, but also to the development of applied colleges and universities facing severe challenges, application-oriented higher education is to adapt to the "Internet + " characteristics of the times, but also to break Traditional teaching bottlenecks, to achieve teaching reform, improve teaching effectiveness and teaching quality, Realizing sustainable development.

The Internet brings great convenience to people's lives. As one of the most important audiences of the Internet, the daily life and learning of contemporary college students are inseparable from the network and gradually affect the life view and values of college students. In December 2015 Held the second session of the Internet summit, President Xi Jinping published the main purpose of "stressed the strengthening of communication, expand consensus, deepen cooperation and jointly build the network space fate community" speech. "Internet + education" [1] [2] to improve the ecological environment of higher education, so that college traditional education glow with a new vitality [3]; for the development of college education and teaching quality to bring new opportunities. But the Internet is a double-edged sword, which brings opportunities to the ideological and political education in colleges and universities, but also to the ideological and political education in colleges and universities to bring new challenges.
\end{abstract}

\section{The Influence of "Internet +" on College Education}

With the deepening of education and teaching reform, computer Internet teaching activities have been significantly improved, especially the development of mobile Internet technology and widely used for educational modernization provides a new technical means, is unprecedented to change people's learning methods, methods and habit. However, there are many problems in the practice teaching mode: Firstly, the computer course teaching activities are basically based on multimedia as the carrier of the theoretical professor. In the era of "Internet +", this teaching model is too much emphasis on theoretical guidance, ignoring the practical ability of students, leading to serious dislocation of theory and practice is not conducive to the development of innovative thinking students, students can't teach students, students have practical ability Not a good training; Secondly, the school network laboratory still can't keep up with the development of social science and technology, and teaching materials do not involve the specific content of network equipment introduced. In addition, the school practice base is relatively few, students are difficult to have more opportunities to participate in the actual work, the lack of practical ability of practical activities; Finally, the practice of teaching content and set unreasonable. In the specific practice teaching, the school set up the experimental class content is less, and mainly the verification of the main experiment, the lack of practicality. At the same time, in the experimental teaching, mostly for students to watch the network environment has been built to learn, the lack of interaction between 
teachers and students is not conducive to stimulate students to learn enthusiasm.

\section{The Reform of Teaching Mode in Colleges and Universities under the Background of "Internet"}

The Change of Classroom Teaching Mode in Colleges and Universities. Based on the "Internet +" era of learners to enhance self-learning awareness, the use of network technology to enrich the teaching model so that Internet technology services in teaching to achieve the purpose of education. Teachers in the teaching model reform need to play a leading role in guiding teachers to take the initiative to carry out education and teaching reform, change the traditional teaching model. To adapt to the modern Internet + era to the teachers of the new requirements, through continuing to learn, training and online video and other means to enhance the teacher's Internet knowledge and teaching software technology to guide teachers to micro classes, MOOC [6], flip the classroom and Mobile classroom and other forms of classroom teaching, the Internet + background of the quality of teachers put forward higher requirements, teachers not only need to master the professional knowledge but also be able to skillfully use digital technology to achieve the teaching objectives [4].

On the Improvement of College Students' Learning Ability. Campus, Classroom, Exam, Evaluation of multimedia. As a result of the use of CD-ROM, Cloud Storage, Big Data and other Large-capacity features [5], more and more teaching materials and tool books into multimedia form, these multimedia materials not only include text and graphics, but also to achieve sound, animation and three The reproduction of the scene, and through the hyperlinks of the way, the relevant information for organic integration, so that information becomes more vivid and practical, more close to the daily life of students, more in line with the needs of students learning. "Internet + Campus" to form a new teaching ecology; "Internet + Evaluation" to the full implementation of the teaching quality monitoring system running [9].

On the Improvement of College Teachers' Educational Ability. As the latest application of talent teachers, but also need to have the talents and talents of applied talents, so we must continue to strengthen the ideological quality of ideological leaders, optimize the knowledge institutions. No matter what kind of practice teaching model, although the students into the theme, but the teacher's guiding role is irreplaceable. Especially the innovative practical teaching ability, requires teachers not only have a high academic level, teaching ability, and must have the enterprise work experience and the rich professional practice experience, therefore, the application type university must strengthen the teacher team construction. On the one hand can be hired from the enterprise high-quality technology, management staff to do part-time teachers, on the other hand to be based on the school, through a variety of ways to enhance the quality of teachers, especially young teachers. For example, the introduction of enterprise talents to enrich the teachers, the organization of teachers on a regular basis in-depth enterprise training, work, to carry out scientific research cooperation with the organization, the organization of young teachers to participate in the relevant professional qualification examination and training.

\section{The implementation of "Multi-Certificate" System}

The "vocational qualification certificate" training and "professional skills certification" into the normal teaching plan, pay attention to cultivate students practical ability, practical ability, to achieve academic education, degree education and professional, vocational qualification training effective combination [7]. After graduation, students can get a degree certificate, degree certificate, vocational qualification certificate, foreign language certificate, computer certificate, etc., to promote the application of undergraduate graduates "than academic undergraduate ability, higher than the higher vocational college students knowledge and ability." 


\section{The Characteristics of Teaching Model Reform in Applied Colleges}

Applicability. No matter what kind of practice teaching model, should be closely around the application of technical personnel training objectives, highlighting the applicability. [8] through practical teaching, to improve student theory with practical ability, the use of professional theory and knowledge to solve practical problems, enhance the overall quality of business and ability to achieve professional application ability, hands-on ability and future career standards Zero docking.

Actual combat. The practice of teaching model used must be able to create real life for students, management, service and other professional environment, select the real project, the real task, the real case, so that students are real engineering and technical management services and other vocational training, Thereby improving practical ability and professionalism.

Openness. Any kind of practice teaching mode, can't be closed, all the experimental, training places are open to the students, to students to self-learning, self-created space. All the practice of teaching links, should try to keep the same industry, business, social contact, or out of the campus, in-depth enterprises and institutions practice, training; or enterprises and technical management personnel invited to the campus, Or a special lecture; or lead enterprises into the school, cooperation and personnel training [10]. So that the school's practice teaching process and the enterprise's production management process relative to maintain the practice of teaching mode of openness, in order to make the school foundation has always deep enterprise, society, to maintain the vitality and vitality of running a school.

\section{Explore the Scientific Business Model}

At present, many online educational resources are free, but free can't support the sustainable development of online education. Network construction requires long-term, substantial investment, relying solely on the strength of the University itself is difficult to support long-term operation[5]. Therefore, both the university's own open platform, or other forms of the establishment of the platform, we must explore the scientific market-oriented operation model, to find a stable and stable financial technical support. From the practice point of view, the Internet companies in the free strategy under the profit model there are two main categories: First, advertising, such as Sina, Baidu, Google, Facebook and other Internet companies are the main income from advertising, most of these enterprises are mass media Business; second is the first free, cultivate customer habits, occupation of the market heights, and then gradually transition to the gradual fee, Taobao is the typical model of this model. The successful experience of these Internet companies are worth learning from "online education". In addition, "online education" can also provide benefits through the provision of extended services, for example, according to the needs of students to provide fees for the completion of the certificate to provide enterprises with targeted training services; or to help enterprises from their graduates to recruit staff; for other universities to provide high Level of course materials. With the "online education" mature and popular in the community to form a network of learning atmosphere and habits can gradually transition to the charging model.

"Internet + " era of the arrival of the education and teaching of colleges and universities has brought great opportunities and challenges to the scientific concept of development point of view, the university teaching reform will inevitably produce pain and risk, but conducive to the future of independent survival and healthy development. With the development of computer information in the direction of the full integration of "Internet + " to implement teaching. College teaching should meet the students 'learning needs, tap the students' interest in learning, mobilize the enthusiasm of students to learn, improve the quality of basic teaching, and strive to cultivate a group of advanced talents with solid theoretical basis and innovative ability and both ability and ability.

\section{References}

[1] Fan WC. Internet + education will produce what chemical reaction [N]. China Youth Daily, 2015-04-08 (6). 
[2] Tang Q. "Internet +" can help education "fly up" [N]. China Education News, 2015-04-07 (8).

[3] Zhou Y. Internet + background under the educational model of exploration [J]. Information and computer, 2015 (23): 187-188.

[4] Wang YD. Internet + time teacher teaching reform [J]. Journal of Science and Education, 2015 (12).

[5] Jing QZ, Xing P. Internet + background under the teaching model innovation research [J]. Education Exploration, 2015 (9): 98-100.

[6] Mushtak Al-Atabi, Jennifer DeBoer. Teaching entrepreneurship using Massive Open Online Course (MOOC) [J].Technovation 34(2014)261-264.

[7] Zhao GQ. "Internet + education": opportunity challenges and response [N]. Guangming Daily, 2015-6-9.

[8] Zhao X. Independent college application technology talent training model research [D]. China University of Geosciences master's degree thesis .2012.5.17-22.

[9] Wu WZ, Guan XH, Qu CY. "Mu class" wave leading the reform of teaching reform [J]. Journal of Northeast Normal University: Philosophy and Social Sciences, 2015, 37 (2): 190-194.

[10]Zhang JJ, Wang HL, Yang ZG. On the inevitability of the reform of classroom teaching mode in applied colleges and universities [J]. University Education, 2016 (3) 17-19. 